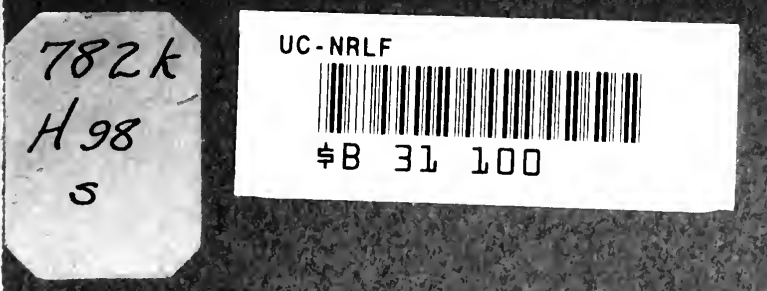




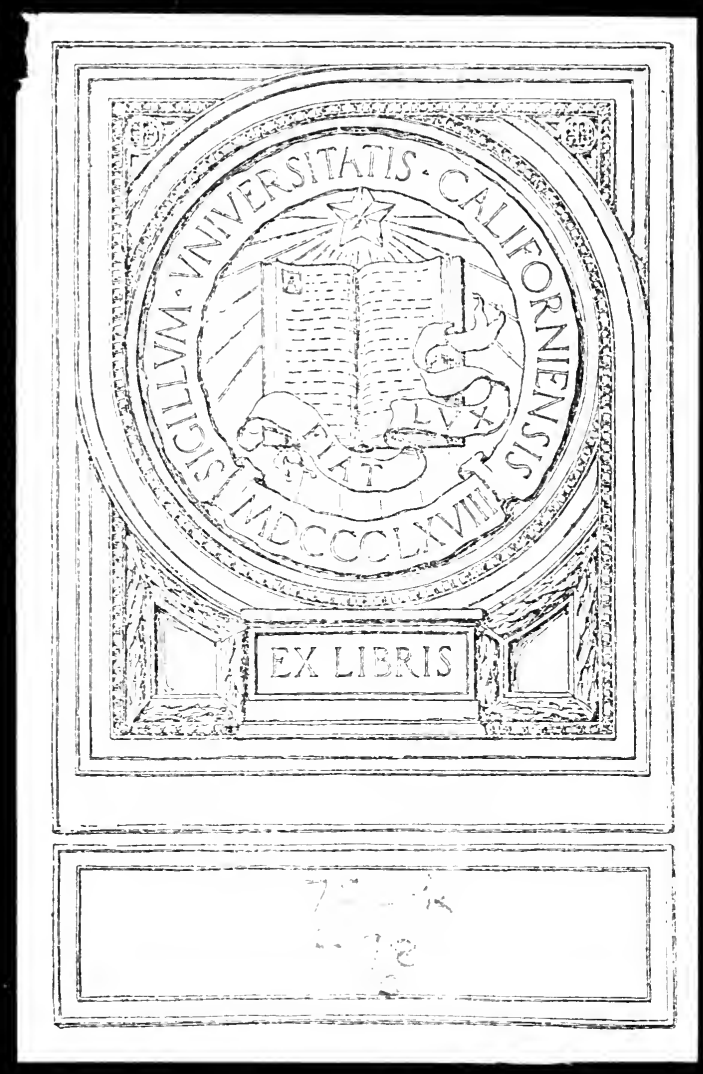


ANNUAL ITALIAN LECTURE

\title{
Some Aspects of the Genius of Giovanni Boccaccio
}

\author{
By \\ Edward Hutton
}

[From the Proceedings of the British Academy, Vol. X]

\author{
London \\ Published for the British Academy \\ By Humphrey Milford, Oxford University Press \\ Amen Corner, E.C.
}





\title{
ANNUAL ITALIAN EECTURE
}

\section{Some Aspects of the Genius} of Giovanni Boccaccio

\author{
By \\ Edward Hutton
}

[From the Proceedings of the British Academy, Vol. X]

\author{
London \\ Published for the British Academy \\ By Humphrey Milford, Oxford University Press \\ Amen Corner, E.C.
}




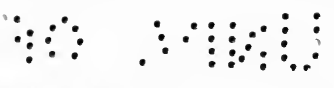

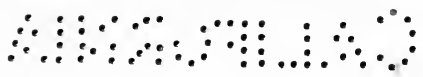




\section{SOME ASPECTS OF THE GENIUS OF BOCCACCIO}

\section{BY EDWARD HU'T'TON}

Read May 24, 1922

IT is my privilege to consider with you this afternoon some aspects of the genius of Giovanni Boccaccio, of his genuis as shown and expressed quite as much in the man himself as in his work. Such a subject, I hope, will not come amiss; for the Annual Italian Lecture last year was concerned, as you will remember, with 'Dante the Poet' and it is surely not unfitting, therefore, that this year we should consider Boccaccio, who was not only the first biographer of Dante and the first public commentator upon the Divine Comedy, but the first great Italian prose writer, even as Dante was the first great Italian poet. Moreover, his most famous book, the Decameron has had at least as great an influence upon European Literature-and not least upon English Literature--as the Divine Comedy, and its author therefore has a great claim upon our respect and, as I hope to show, upon our affection.

Now in any consideration of Boccaccio, here in England especially, I think we ought first to seize this fact in regard to him : namely, that he wrote a great many books beside the Decameron: that his really immense services to Literature and to Humanism are by no means summed up in that ever-living book.

For Boccaccio was not only the great creative artist who finally produced that vast Human Comedy the Decameron, he was also a great and heroic soldier in the cause of Humanism, of the Revival of Learning. Having spent half his life in the writing not of the Decameron alone, but of eight or nine original works in the 'Tuscanthe Filocolo, the Filostrato, the T'eseide, the Ameto, the Amorosa Visione, the Fiammetta, the Ninfale Fiesolano and the Corbaccio, to say nothing of his Sonnets and his Vita di Dante, the earliest biography of the poet; he turned, still with an immense enthusiasm and energy, to the spade-work of learning, and not only produced in his Latin works books of reference and information and criticism upon which learning at that time came largely to depend, but took into his house a vagabond and a rogue, and by his side day after day, month after month, with long endeavour, self sacrifice and love, often in tears, often weary, but never losing heart, procured for us the first translation of Homer, and once more put us in possession of the greatest of all epic poems. 
$\therefore: \therefore \cdots: \therefore$ : $\therefore$

it. is only frejudice arat-perhaps ignorance that can dismiss such a man as a mere purveyor of doubtful stories: nor indeed can Boccaccio, though he had done nothing but write the Decameron be reasonably regarded in such a light. The work in which Chaucer, Sidney, Shakespeare, Dryden, Keats, and 'Tennyson - to name only a few among our poets-read with delight, finding there what they wanted, is necessarily something living and splendid, and is still able to entrance and to influence the noblest minds of our race.

Now in the life of this great and heroic man there were two decisive experiences which influenced and even directed the whole of his work. The two events were his meeting with, and love for Fiammetta-Maria d'Aquino that is, the bastard daughter of King Robert of Naplesand his meeting with and friendship for Petrarch.

He met Fiammetta at the age of twenty-three in 1336, and for twelve years at least, till she died in the Black Death of 1348, under the influence of his love for her, he is a great imaginative artist. It was for her he wrote all his works, among them the first psychological novel in the Italian language.

A period of bitterness and disillusion follows which had long been preparing and which gives us that amazingly bitter and malicious work Il Corbaccio. To escape this he turns to religion and to the study of Dante; and then to save himself, perhaps from a sort of melancholy, under the influence of his friend Petrarch, he throws himself with renewed energy into scholarship, into the re-discovery and revival of the learning of antiquity.

His legend, as the French say, has been built up by piecing together the various accounts he himself gives of his love story, chiefly in the Filocolo, the Ameto and the Fiammetta. Thus, we learn that he first met Fiammetta in Naples in the Church of San Lorenzo of the Franciscans on a certain Holy Saturday-as scholarship has now practically decided in the year 1336. He had gone to Mass it seems about ten o'clock in the morning, the fashionable hour of the day, rather to see the people than to attend the service, and there amid that great throng of all sorts and conditions of men, he first caught sight of the woman who was so profoundly to influence his life and shape his work:

The love story thus begun, if we interpret his own accounts aright, may be divided into four periods. The first of these ends twelve days after the first meeting and is the period of uncertainty. The second is that in which he is accepted as a courtier, as it were on trial. The third begins when his lady, moved by long service and repeated proofs of devotion, returns his love; it is the period of 'dolce signoria' and 
lasts 135 days, at the end of which she gives herself to him and they are happy through a whole summer. The fourth begins with jealousy and ends with open rupture, the cause of which he always declares he never knew ; his betrayal and desertion by Fiammetta. His love affair was at an end and was never renewed; but it fills his whole life and inspires every book he wrote before the Ninfale Fiesolano and the Decameron.

He came back into the delicate and strong Florentine country really to lose himself in work. But during his love affair with Fiammetta in Naples he had already begun three works and probably finished two of them: the Filocolo, the Filostrato and the Teseide.

His state of mind is visible in his work which is so extraordinarily personal. A single thought seems to fill his mind: he had loved a princess and had been loved in return; she had forsaken him; but she remained in spite of everything the lode-star of his life. $\mathrm{He}$ writes really of nothing else but this. Full of her he sets himself to enchant her with stories, to glorify her, to tell over and over again his own story.

It was the story of Florio and Biancofiore which had charmed Fiammetta at first hearing, when Giovanni told it to her in the convent parlour at Sant' Arcangelo a Baiano, and it is round this tale that the Filocolo is written. As he tells us himself in the first page this was the first book he made to please her. As we have it it is the longest of his works after the Decameron, and the weakest of all. Boccaccio seems to have felt this for he abandoned the work upon it in Naples at the end of the third book-the work consists of seveneither for this cause or because his love affair had changed in character and he felt the need of expressing what he was suffering. What this was is very obvious to us in his next work the Filostrato in which he tells, using ottava rima for the first time in Italian literature, the story of Troilus and Cressida.

'You are gone suddenly to Samnium' he writes in the dedication to Fiammetta ' and ... I have sought in the old histories what personage I might choose as messenger of my secret and unhappy love, and I have found 'Troilus son of Priam who loved Criseyde. His miseries are my history. I have sung them in light rhymes and in my own 'Tuscan, and so when you read the lamentations of Troilus and his sorrow at the departure of his love, you shall know my tears, my sighs, my agonies, and if I vaunt the beauties and the charms of Criseyde you will know that I dream of yours.' Well, the intention of the poem is just that. It is an expression of his love. He is tremendously interested in what he has suffered; he wishes her to know of it, he is eager to tell of his experiences, his pains and joys. The story is the 
merest excuse, a means of self-expression. And yet in its exquisite beauty of sentiment and verse it is one of the loveliest and most spontaneous of his works. One too which has a special interest for us, for Chaucer drew upon it very largely for his Troilus; no less than 2700 lines, nearly half the Italian poem being literally translated by Chaucer into English. This is about a third of Chaucer's poem.

If we had any doubt as to Boccaccio's state of mind, his next work the Teseide would make it clear to us. It is full of the agonies of his jealousy. It is prefaced by a letter to Fiammetta in which he tells her he has written this poem to please her 'thinking of past joy in present misery.' As for the content it will be enough here to say that it provided Chaucer with his 'Knight's 'Tale' in the Canterbury Tales. It is the second of Boccaccio's epic poems. It was begun in the shadow of Virgil's tomb, and to some extent was modelled upon the Aeneid, though Boccaccio borrowed too from Statius and from the Roman de Thêbes. It is written like the Aeneid in twelve books and has precisely the same number of lines as Virgil's great poem, (9896). It is, therefore, about twice as long as the Filostrato.

Had he some idea of winning back her love by this stupendous manuscript? How charming and how naïve, how like Giovanni too; but how absurd to dream of thus influencing a woman. Did she ever read these nine thousand odd verses? Chaucer read it, however, and translated it or rather paraphrased it for the Knight's Talefirst of the Canterbury Tales.

In Naples, in the shadow of Virgil's tomb, in a classic country still full of that old renown, Boccaccio had followed classic models, had begun two epics and a romance in the manner of Apuleius; but in Tuscany the country of Dante and Petrarch he came under the influence of different work, and we find him writing a sort of Dantesque allegory of prose scattered with verses. The action of the Ameto takes place in the country about Florence, under the hills of Fiesole in the woods there above Corbignano where his father had a villa and podere. The book looks backward and forward like the Filocolo. It is as autobiographical and more self-revealing than that romance, and we seem to gather that he has still some hope of winning back Fiammetta. She indeed appears as Hope and he as Despair in the most significant part of the work, where we see a reunion of seven nymphs and shepherds disguised as the cardinal and theological virtues and their affinities, to discuss questions of love and to tell stories. Here again, as in a scene, the Questioni dAmore of the second part of the Filocolo, is the scheme of the Decameron in the making. 
There follows the Amorosa Visione which was almost certainly begun immediately after the Ameto. It recalls the happier time of his love, and Fiammetta is the very soul of the poem which is dedicated to her in an acrostic to be solved by reading the initial letters of the first verse of each terzina, the result being two sonnets and a ballata. The name Madonna Maria is formed by the initials of the twelfth to the twenty-second terzina of Capitolo $\mathrm{X}$, and the name 'Fiamma' by those of the twenty-fifth to the thirty-first of Capitolo XIII. The last three lines of the first sonnet thus obtained read: 'Dear Fiamma for whom my heart burns he who sends you this Vision is Giovanni di Boccaccio da Certaldo.'

This poem, as the title proclaims, is a vision-a vision which Love discovers to the poet-lover. Therein he sees four 'Triumphs-of Wisdom, of Fame, of Love and of Fortune. These Trionfi, the first of the kind in Italian literature, are said to have been written before the more famous Trionfi of Petrarch; they owe nothing to Petrarch; but the whole poem shows us that Boccaccio was already studying the Divine Comedy very closely. Written in the same form of verse as Dante's great work, the Amorosa Visione derives from it too, in all probability, the precision of its construction. It consists of fifty capitoli, each composed of twenty-nine terzine and a verse of chiusa, that is of eighty-eight verses in each.

Let us now turn to the Fiammetta for a moment: the last work directly concerned with his passion for Maria d'Aquino. The action is very simple, but it is remarkable in this. Here we have the love story of Boccaccio told by Fiammetta as though it were her autobiography. It is, in fact, the first psychological novel of Europe. And in some sort it is his revenge upon her: for here it is she who is deserted not he. It is she who weeps and Giovanni who laughs or is indifferent.

As a work of art the Fiammetta is the best thing Boccaccio has done up to this time. The psychology is subtle and full of insight, but not so dramatic nor indeed so profound as in the Filostrato. We see Fiammetta's continual doubts of herself for he gives her his gift of introspection. We see her soul tormented as his had been, the fury of jealousy that had been his. The work is absolutely original-the crowning work of his youth. And in a sense it freed him. He writes no more of his love story. He turns away from all that misery and writes a delicious idyll the Ninfale Fiesolano, the most mature of his poems. He shows himself there to be a poet indeed, and though the theme is still love-the loves of Affrico and Mensola, two small streams that flowed by his father's house at 
Corbignano, all the bitterness of that theme for him is lost in music. He describes with the greatest affection and enthusiasm this country he loved best between the village of Settignano and Fiesole, north and east of Florence, as though he can never forget the lines of just those hills, the shadows on the woods there, the darkness of the cypresses over the olives. 'This is the third poem he wrote in ottave, a form of which he is certainly the first real exponent.

All that bright world about Florence among the woods of Vincigliata under Fiesole and the olive gardens and podere of Corbignano, on the banks of Affrico and Mensola, so full of voices for Boccaccio, where his earliest years had been spent, as we may think, and which he celebrates and expresses so exquisitely in the Ninfale, was presently silenced by the most appalling calamity that has perhaps ever befallen Europe-the Black Death of 1348. Three out of every five persons died in Florence. The grass grew in the streets. 'So completely were all obligations of blood and of affection forgotten,' Filippo Villani tells us, "that men left their nearest and dearest to die alone rather than incur the dangers of infection.' People said the end of the world had come. In a sense they were right. It was the end of the Middle Age.

In Florence there perished among the rest Giovanni Villani the great chronicler, and Bice the second wife of Boccaccio. In Naples it seems certain that Fiammetta died.

We do not know where Boccaccio was at this time. He was not in Florence. Did he perhaps close Fiammetta's eyes and bear her to the grave? If he did he was soon recalled to Florence by his father's death. And there, after that vengeance whether of God or of outraged nature in which all those he loved or cared for had been lost to him, he set himself to put in order that great Human Comedy which has given him immortality.

In the very opening page of the Decameron, we see that even after writing six works in prose and verse about her, even now she is dead he cannot forget Fiammetta. The great Proem opens with her unspoken name and closes too in the same fashion. Moreover, of those seven ladies and four youths who are the protagonists of the Decameron, it is only she named Fiammetta who lives. The others are without any personality at all, mere lay figures. As for Boccaccio himself you will scarcely find him in all the hundred tales of the Decameron.

It is strange that the work which best represents his genius, his humour and wide tolerance and love of mankind, should in this be so opposite to all his other works in the vulgar tongue, which are 
inextricably involved with his own personal affairs, his view of things, his love, his contempt, his hatred.

He speaks to us there once or twice, but always outside the stories, and his whole treatment of the various and infinite plots, incidents, and characters of his great work is as impersonal as life itself.

'The Decameron is an absolute work of art, as 'detached' as a play by Shakespeare or a portrait by Velasquez. The scheme is formal and immutable, a miracle of design in which almost everything can be expressed. To compare it with the plan of the Arabian Nights is to demonstrate its superiority. There you have a sleepless king, to whom a woman tells a thousand and one stories in order to save her life which this same king would have taken. You have, then, but two protagonists and an anxiety which touches but one of them, the fear of death on the part of the woman, soon forgotten in the excitement of the stories. In the Decameron, on the other hand, you have ten protagonists, three youths and seven ladies, and the horror which is designed to set off the stories is an universal pestilence which has already half depopulated the city of Florence, and from which they are fled away to the exquisite seclusion and delight of a great villagarden on the slopes under Fiesole, where they spend their time in telling the stories that have made this work immortal.

Such is the incomparable design which the Decameron fills, beside which the mere haphazard telling of The Hundred Merry T'ales seems barbarous, the setting of The T'housand and One Nights inadequate. 'That Boccaccio's design has indeed ever been bettered might well be denied, but in The Canterbury Tales Chaucer certainly equalled it. If the occasion there is not so dramatic, nor the surroundings at once so poignant and so beautiful, the pilgrimage progresses with the tales and allows of such a dramatic entry as that of the Canon and the Canon's yeoman at Boughton-under-Blee. 'That entry was most fitting and opportune, right in every way, and though there is no inherent reason why the Decameron itself should not have been similarly broken in upon, the very stillness of that garden in the sunshine would have made any such interruption less acceptable. ${ }^{1}$ The true weakness of the plan of the Decameron in comparison with that of The Canterbury T'ales is not a weakness of design but of character. Each of Chaucer's pilgrims is a complete human being; they all live for us more vividly than any other folk, real or imagined, of the fourteenth century in England, and each is different from the others,

1 The only interruption of the Decameron, if so it can be called is the introduction of Tindaro and Licisca at the beginning of the sixth day. The diversion, however, has very little consequence. 
a perfect human character and personality. But in the protagonists of the Decameron it is not so. There is nothing, or almost nothing, to choose between them. Lauretta is not different from Filomena, and may even be confused with Dioneo or Filostrato. We know nothing of them ; they are without any character or personality, and indeed the only one of them all who stands out in any way is she called Fiammetta, and that because she never appears but Boccaccio intervenes to tell us something of her or to describe her beauty.

In Chaucer the tales often weary us, but the tellers never do; in Boccaccio the tales never weary us, but the tellers always do. The tales never weary us. The Decameron is a world in itself, and its effect upon us who read it is the effect of life which includes, for its own good, things moral and immoral. The book has the variety of the world, and is full of an infinity of people, who represent for us the fourteenth century in Italy, in all its fullness, almost. It deals with man as life does, never taking him very seriously, or without a certain indifference, a certain irony and laughter. Yet it is full too of a love of courtesy, of luck, of all sorts of adventures, both gallant and sad. In details, at any rate, it is true and realistic, crammed with observations of those customs and types which made up the life of the time. It is dramatic, ironic, comic, tragic, philosophic, and even lyrical; full of indulgence for human error, an absolutely human book beyond any work of Dante's or Petrarch's or Froissart's. Even Chaucer is not so complete in his humanisim, his love of all sorts and conditions of men. lerfect in construction and in freedom, each of these tales is in some sort a living part of life, and a criticism of it. And almost any one could be treated by a modern writer in his own way, and remain fundamentally the same and fundamentally true. What immorality there is, is rather owing to the French sources of some of the tales, than to any invention on the part of Boccaccio, who softened much of their original grossness, and later came to deplore what remained.

But it is in its extraordinary variety of contents and character that the Decameron is chiefly remarkable. We are involved in a multitude of adventures, are introduced to innumerable people of every class, and each class shows us its most characteristic qualities. Yet such is Boccaccio's art, the stories were not originally, or even as they are, ostensibly studies of character at all but rather anecdotes, tales of adventure, stories of illicit love, good stories about the Friars and the clergy, and women, told for amusement because they are full of laughter or are witty, or contain a brief and ready reply with which one has rebuked another or saved himself from danger. 
Whatever they may be, and they are often of the best, of the most universal, they are not, for the real lover of the Decameron, the true reason why he goes to it always with the certainty of a new joy. The book is full of people, of living people-that is the secret of its immortality. Fra Cipolla, whom I especially love, Celandrino whom I seem always to have known, poor Monna 'Tezza his wife whom at last he so outrageously gives away, Griselda, Cisti the Florentine baker, the joyous Madonna Filippa or Monna Belcolore should be as dear to us as any character in any book not by Shakespeare himself. They live for ever. And yet it must be confessed that while the book is a mirror of the world, and doubtless as true to the life of its time as any book that was ever written, it lacks a certain idealism, a certain moral sense, which even from a purely aesthetic point of view would have given a balance, a sense of proportion to the book which it has sometimes seemed to me it lacks.

But after all when we compare it even with the Divine Comedy, it holds its own because of its humanity, and we may claim for it that it is the greatest as it is the first prose work in the Tuscan tongne.

With the Decameron, Boccaccio's work as a creative artist comes to an end. It is true that we have that mysterious and savage satire the Corbaccio, begun immediately after the Decameron was finished, that is to say, about 1353; but the passion which had given him expression, inspired everything he had done and made him a great creative artist has there turned sour-sneers, as it were, at itself, and we get that wild invective, laughable in its wildness and unmeasured malice, against Woman which characterizes it. It was written he said to open the eyes of the young to the horror of woman. From this time-he was more than forty years old-he ceases to be a creative artist. Fiammetta is dead, and what henceforth fills his life is friendship-friendship for Petrarch, which with all its comfort left him still with that vain shadow, that emptiness in his heart-

'The grief which I have borne since she is dead.'

But before he gave himself wholly to his friend he turned for consolation to the study of his great predecessor Dante. As soon as the Corbaccio is finished we find him at work on the Vita di Dante, the earliest life of the poet, and it is coloured with his misery.

About the same time he seems to have begun to copy the Divine Comedy with his own hand in order to send it to Petrarch, and we may understand perhaps how great a pioneer he was in the appreciation of Dante when we learn, from this fact, that Petrarch had no copy in his library. Petrarch had indeed ceased to be interested in 
Italian literature; and it is significant that in the very year in which Boccaccio presents him with this copy he had himself made for him of Dante's poem, he obtained for Boccaccio a manuscript of Homer.

Even in his youth Boccaccio had regarded Petrarch with an enthusiasm and an unenvying modesty, that, lasting as it did his whole life long, ripening as it did into one of the greatest friendships in the history of Letters, was perhaps the most beautiful trait in his character. It always seemed to him an unmerited grace that one who was sought out by Popes and Princes, whose fame filled the universe, should care to be his friend; and this wonder, this admiration remained with him till death. He never writes Petrarch's name without, in his enthusiasm, adding to it some flattering epithet. $\mathrm{He}$ calls him his 'illustrious and sublime master', his 'father and lord', 'a poet who is rather of the company of the ancients than of this modern world', ' a man descended from heaven to restore to Poetry her Throne', the 'marvel and glory' of his time. He had known and loved his work as he says for many years, but it seems he had never dared to approach him though opportunities had not been lacking, till Petrarch came to Florence in the autumn of 1350 on his way to win the Indulgence of the Jubilee in Rome. 'This is the beginning of that friendship which is almost without precedent or imitation in the history of Literature.

In the following spring, the spring of 1351, Boccaccio in the name of Florence went to Padua to recall Petrarch from exile, to offer him a chair in the new university of his native city and to restore him the goods confiscated from his father. In Padua he was Petrarch's guest for some days; he was a witness of Petrarch's enthusiasm for 'sacred studies', and it might seem that ever since this visit he had come under Petrarch's influence, and in intellectual matters at any rate, had been very largely swayed by him. More and more, in accordance with the unfortunate doctrine of his master, we see him, after 1355, giving up all work in the vernacular and setting all his energy on work in the Latin tongue, in the study of antiquity and the acquirement of learning. From a creative writer of splendid genius he became a scholar, a scholar of vast reading but of mediocre achievement. He seems to have read without ceasing the works of antiquity, assimilating as he read. His learning, such as it was, became prodigious, immense, and in a sense universal; and little by little, he seems to have gathered his notes into the volumes we know as: De Montibus, Sylvis, Fontibus, \&c., a sort of Dictionary of Geography; the De Casibus Virorum Illustrium, in nine books, which deals with the vanity of Human affairs from Adam to his own time; the De 
Claris Mulieribus which begins with Eve and comes down to Giovanna Queen of Naples, and the De Genealogiis Deorum in fifteen books, a cyclopaedia of learning concerning mythology, and a defence of poetry and poets. In all these works it must be admitted that we see Boccaccio as Petrarch's disciple, a disciple who lagged very far behind his master.

As a creative artist, as the author, to name only the best, of the Fiammetta, the Ninfale Fiesolano and the Decameron, Boccaccio was the master of a world Petrarch could not enter; he takes his place with Dante and Chaucer and Shakespeare, and indeed save Dante no other writer in the Italian tongue can be compared with him.

It is seldom, however, that a great creative artist is also a great scholar, for the very energy and virility and restless impatience which have in some sort enabled him to create living men and women prevent him in his work as a student, as an historian pure and simple, in short as a scholar. So it is with Boccaccio. The author of the Latin works is not only inferior to the author of the Fiammetta and the Decameron, he is the follower and somewhat disappointing pupil of Petrarch, who contrives to show at every step his inferiority to his master :-as a student, as a man of culture in a sense of the reality of history, in a due sense of the proportion of things. For Petrarch antiquity was a practical school of life. Convinced of the superiority of his spirit, he possessed himself of what he read and assimilated what he wanted. Boccaccio, on the other hand, remains entirely outside, and can claim little merit as a scholar but that of industry. As a student he is a mere compiler. His continual ambition is to extend his knowledge; but Petrarch dreams only of making his more profound. He too, in reading the ancients, has collected an incalculable number of extracts, but after putting them in order from various points of view he has only begun; he proceeds to draw from them his own works.

In all these things and in many others Boccaccio is little more than Petrarch's disciple, following him without discrimination, more violent in his abuse, more extreme in his advocacy of those things, or professions, or ideas or people whom his master had come to consider as good, reasonable, or unreasonable. And so it is not in his Latin works, all of which are vast dictionaries of learning and legend, that we shall find the man of genius that dazzles us in the Decameron. Yet these works must not be too much depreciated. 'Ihey rendered great service, their very great usefulness is witnessed by their enormous popularity and the large number of editions through which they have passed. 'They were the text-books of the early Renaissance, and we 
owe Boccaccio, as one of the great leaders of that movement, all the gratitude we can give him; all the more that the work he began has been so fruitful that we can scarcely tolerate the works that guided its first steps.

But the most moving event in this story of the Revival of Learning in its relation to Boccaccio and to Petrarch offers us what is I think an unmatched example of the pathos of friendship and the beauty of Letters.

In 1353 Petrarch had met in Avignon an ambassador of the Emperor at Constantinople, and in the following year this man Nicolas Sigeros had sent him as a gift the Greek text of the Iliad and the Odyssey. The poet received them with an enthusiastic letter of thanks, at the same time confessing his insufficiency as a Hellenist.

Some years later in the winter of 135̃-9, during a sojourn at Padua, there was introduced to Petrarch a certain Leon Pilatus who gave himself out for a Greek, and the poet seized the opportunity to get a translation of a part of his MS. of Homer. In the spring, however, he went to Milan where Boccaccio 'troubled in spirit' and immersed in the study of Dante visited him, and it is probable that Leon Pilatus was of the company. It is certain that Petrarch spoke of him, and that Boccaccio invited him to visit him. That invitation was accepted, and before the end of the year we see Pilatus established in Florence.

'This man who makes such a bizarre figure in Boccaccio's life seems to have belonged to that numerous race of adventurers half Greek, half Calabrian, needy, unscrupulous, casual and avaricious, who ceaselessly wandered about Europe in the fourteenth and fifteenth centuries seeking Fortune. It might seem strange that such an one should have played the part of a teacher and professor; but he certainly was not particular, and Petrarch and Boccaccio were compelled to put up with what they could get. Pilatus, however, seems to have wearied and disgusted Petrarch; it was Boccaccio, more gentle and more heroic, who devoted himself to him for the sake of learning. Having persuaded Pilatus to follow him to Florence he caused a Chair of Greek to be given him in the university, and for almost four years imposed on himself the society of this disagreeable barbarian. For as it seems he was nothing else, his one claim on the attention of Petrarch and Boccaccio being that he could, or said he could, speak Greek. We know very little about him. He boasted that he was born in Greece, but later owned that he was a Calabrian. His appearance according to Boccaccio and Petrarch had something repellant about it. His crabbed countenance was covered with 
bristles of black hair, an untended beard completing the effect, and his ragged mantle only half covered his dirty person. Nor were his manners more refined than his physique; while his character seems to have been particularly disagreeable, sombre, capricious, and surly. Petrarch confesses that he had given up trying to civilize this rustic, this 'magna bellua.'

Such was Leon Pilatus; but for the love of Greek Boccaccio pardoned everything, and he and two or three friends, the only persons in Florence indeed able to do so, followed the lectures of this improvised professor. But it was above all in admitting this creature to his house that Boccaccio appears most heroic. 'There he submitted him to long interviews and interminable seances in order that he might accomplish the long task of a complete translation of Homer.

Afar off Petrarch associated himself with this work, and tried to direct it with wise counsels, that Leon Pilatus was doubtless too little of a scholar to understand, and too ignorant to follow blindly. In fact, but for Petrarch they would have lacked the text itself.

From a letter of Petrarch's we may gather how eagerly Boccaccio had turned to this new labour. Was it in order to escape from himself? It may be that in this new enthusiasm he found, for a time at any rate, a certain consolation; but the crisis long threatened was not long delayed. In those long months while the wretched Pilatus was with him, however, he was able for a time to ward off the danger ; and realizing this the comedy of that friendship is almost pathetic.

We seem to see him eagerly drinking in the words that fell from the surly Pilatus, pressing him with questions, taking note of all and trying to understand everything - even what his master himself could not understand. As for that master, flattered and puffed up by the confidence that Boccaccio seems to have felt in him, he no doubt replied to all his questionings in the tone of a man who knew perfectly what he was talking about and had nothing to fear or to hide. Sometimes no doubt the adventurer showed itself. Weary and bored by the incessant work, his sullen humour exasperated by the sedentary life, Pilatus would demand his liberty. Then Boccaccio would have to arm himself with all his patience, and by sweetness and gentleness and good humour would at last persuade the wretched man to remain a little longer with him.

It was in the midst of this difficult work with Pilatus that his trouble descended upon him with a supernatural force as he thought. He received a message from a dying saint-a message that warned him of his approaching end and certain damnation unless he should 
repent. When exactly this message reached him we do not know. It may well have been in the end of 1361 , but it was more probably in the first months of 1362. He was in any case in no fit state to meet the blow.

In those days when political crises followed hard on one another and the very aspect of a city might change in the course of a few years Boccaccio's youth must then have seemed infinitely far away. While in very many ways he is the pioneer of the Renaissance, in his heart there lingered yet something, if only a shadow, of the fear of joy. All his joys had been adventures on which he scarcely dared to enter, and he was so perfectly of his own time as to 'repent him of his past life'. For a nature like that of Boccaccio was capable only of enthusiasm. He had loved Fiammetta to distraction; when Fiammetta died, the very centre of his world was shaken; he could not follow her through Hell and Purgatory into the meadows of Paradise as Dante had followed Beatrice; he was of the modern world.

Having the religious sense he accused himself of sin as St. Paul had done, as St. John of the Cross was to do, with an astonishing eccentricity, an exaggeration which lost sight of the truth, in a profound self-humiliation. He too had found it difficult 'to keep in the right way amid the 'Temptations of the world'. And then suddenly, it seems on the threshold of old age, poor and alone he thought to love God with the same enthusiasm with which he had loved life. He was not capable of it; his whole past rose up to deny him this impassioned consolation, and his 'spirit was troubled' as the wise and steadfast eyes of Petrarch had seen.

It was in the midst of this disease, to escape from which as we may think he had so eagerly thrown himself into the translation of Homer with Pilatus that a certain Gioacchino Ciani sought him out to warn him, as he intended to warn Petrarch, of the nearness of death. In doing this the monk, for he was a Carthusian, was but obeying the dying commands of the Beato Pietro Petrini, a Sienese who had seen on his death-bed the present, the past, and the future. Already driven towards a new life-a life which under the direction of the Church he was told would be without the consolations of literatureat the sudden intervention as it seemed of heaven, Boccaccio did the wisest thing of his whole life, he asked for the advice of Petrarch.

The letter which Petrarch wrote him takes its rank among the noblest of his writings and is indeed one of the most beautiful letters ever written.

'Your letter', he says-'Your letter, my brother, has filled me with an extraordinary trouble. In reading it $I$ became the prey of a great 
astonishment and also of a great chagrin : after reading it both the one and the other have disappeared. How could I read without weeping the story of your tears and of your approaching death, being totally ignorant of the facts and only paying attention to the words? But at last, when I had turned and fixed my thoughts on the thing itself, the state of my soul changed altogether, and both astonishment and chagrin fled away. . . You tell me that this holy man had a vision of our Lord, and so was able to discern all truth-a great sight for mortal eyes to see. Great indeed I agree with you, if genuine; but how often have we not known this tale of a vision made a cloak for an imposture? And having visited you, this messenger proposed I understand to go to Naples, thence to Gaul and Britain, and so to me. Well, when he comes I will examine him closely;his looks, his demeanour, his behaviour under questioning, and so forth shall help me to judge of his truthfulness. And the holy man on his death-bed saw us two and a few others to whom he had a secret message, which he charged this visitor of yours to give us; so, if I understand you rightly, runs the story. Well, the message to you is twofold; you have not long to live, and you must give up poetry. Hence your trouble, which I made my own while reading your letter, but which I put away from me on thinking it over, as you will do also; for if you will only give heed to me, or rather to your own natural good sense, you will see that you have been distressing yourself about a thing that should have pleased you. Now if this message is really from our Lord it must be pure truth. But is it from our Lord? Or has its real author used our Lord's name to give weight to his own saying? I grant you the frequency of deathbed prophecies ; the histories of Greece and Rome are full of instances; but even though we allow that these old stories and your monitor's present tale are all true, still what is there to distress you? What is new in all this? You knew without his telling you that you could not have a very long space of life before you. And is not our life here labour and sorrow, and is not its chief merit that it is the road to a better?... Ah! but you have come to old age, says your monitor. Death cannot be far off. Look to your soul. Well, I grant you that scholarship may be an unreasonable and bitter pursuit for the old, if they take it up then for the first time; but if you and your scholarship have grown old together, 'tis the pleasantest of comforts. Forsake the Muses, says he: many things that grace a lad are a disgrace to an old man; wit and the senses fail you. Nay, I answer, when he bids you pluck sin from your heart, he speaks well and prudently; but why forsake learning, in which you are no novice but 
an expert?... All history is full of examples of good men who have loved learning, and though many unlettered men have attained to holiness, no man was ever debarred from holiness by letters. . . But if in spite of all this you persist in your intention, and if you must needs throw away not only your learning, but the poor instruments of it, then I thank you for giving me the refusal of your books. I will buy your library if it must be sold, for I would not that the books of so great a man should be dispersed abroad and hawked about by unworthy hands. I will buy it and unite it with my own; then some day this mood of yours will pass, some day you will come back to your old devotion. Then you shall make your home with me, you will find your books side by side with mine, which are equally yours. 'Thenceforth we shall share a common life and a common library, and when the survivor of us is dead, the books shall go to some place where they will be kept together and dutifully tended, in perpetual memory of us who owned them.'

That noble letter, so sane in its piety, in some sort cured Boccaccio. We hear no more of the fanatic monk, and the books were never bought by Petrarch for they were never sold.

When he had read Petrarch's letter and come to himself Boccaccio returned to Pilatus and finished the translation of Homer. Later he sends the Iliad and part of the Odyssey to Petrarch who had it copied, and it is this manuscript which is now in Paris.

Boccaccio with a charming and naive sincerity owns that he did not understand much, but adds that the little he did understand seemed beautiful. He was very proud of his victory, and rightly; for by its means the Renaissance was able to give Homer his right place in its culture.

That wise and witty letter had in some sort cured Boccaccio, yet not finally. More and more he turns to his master, and in 1366 troubled again in spirit and, as it seems, very poor, he suddenly decided to set out for Venice to see him. He left Certaldo on March 24, but coming to Florence 'The continual rains, the dissuasions of friends, and the fear of the dangers by the way', added to the tales of those who had made the journey from Bologna, caused him to hesitate. So that when he arrived in Venice, at last, he found Petrarch gone. He writes him at once to tell him of his reception, and it is in this letter that we see another and unsuspected side of his genius-his love of children. He is speaking of Petrarch's daughter 'Tullia. 
'After reposing myself a little (he writes to Petrarch) I went to salute 'Tullia who had already heard of my arrival ... She met me joyfully, blushing a little and looking on the ground, with modesty and filial affection, and she saluted and embraced me. . . . Presently we were talking in your charming little garden with some friends, and she offered me with matronly gravity your house, your books and all your things there. Suddenly, little footsteps, and there came towards us thy Eletta, my delight who, without knowing who I was, looked at me smiling. I was not only delighted; I greedily took her in my arms imagining that $I$ held my little one that is lost to me. What shall I say? If you do not believe me, you will believe Guglielmo da Ravenna the physician and our Donato who knew her. Your little one has the same aspect that she had who was my Eletta, the same expression, the same light in the eyes, the same laughter there, the same gestures, the same way of walking, the same way of carrying all her little person; only my Eletta was, it is true, a little taller when at the age of five and a half I saw her for the last time. Besides she talks in the same way, uses the same words and has the same simplicity. Indeed, indeed there is no difference save that thy little one is golden haired, while mine had chestnut tresses. Ah me! How many times, when $I$ have held thine in my arms listening to her prattle, the memory of my baby stolen away from me has brought tears to my eyes-which I let no one see.'

Boccaccio's XIVth Eclogue which tells us so much that otherwise we should never know as to his children, for it seems he had several children, is entitled Olympia. Olympia was Violante, and it is of Violante he is speaking in that letter. This Eclogue has been translated into English verse and edited and published with the Latin original and extracts from Boccaccio's letter, which I have translated above, by Professor Sir Israel Gollancz. I think he must have been the only man in England who remembered the sixth centenary of Boccaccio's birth in 1913, and it was just like him to celebrate it in so exquisite a way.

'That love of children, so characteristic in an Italian, and yet so surprising in Boccaccio to those who, without understanding the real simplicity of his nature, have been content to think of him as a mere teller of doubtful stories, is one of the most natural and beautiful traits in his character. Nor is this by any means the only glimpse he gives us of his interest in children. Apart from the neglected portraits of the Decameron we find him referring to them, their health and upbringing in the Commentary on the Divine Comedy, when he speaks of the danger they are in from careless and neglectful nurses, who put 
them to rest or sleep in the light, and thus hurt their eyes and induce them to squint: and yet he can believe, though probably with less than the common conviction, that a squint is the sign of an evil nature, dangerous alike to the afflicted person and to those whom he may encounter.

That vision of Violante, 'my delight', appears like a ray of sunshine in a lonely and even gloomy old age which, had she lived, we may think might have been less bitter, less hard to bear than it proved to be.

Hard and bitter it was, and passed in poverty. It is possible that his friends in Florence, hearing of his miseries, founded the first Cathedra Dantesca to relieve him. He had always been an eager defender of the Divine Comedy and of Italian literature, and his own Decameron was to prove to be not only the greatest prose work in the language, but the most fruitful and of the most far-reaching influence.

He delivered his first lecture in the Church of Santo Stefano on Sunday, October 23, 1373, at the age of 60. Already an old man, infirm in health, he can scarcely have hoped to finish his work and, as it proved, he was not able to complete a sixth part of it, for attacked by illness in the winter of 1373 he broke off abruptly at the seventeenth verse of the seventeenth canto of the Inferno and returned to Certaldo really to die. The disease which thus declared itself was no new thing. In his versatile and athletic spirit there had always been a strain of melancholy that had shown itself in his earliest childhood when he imagined he was persecuted; on his arrival in Naples as a boy when only a kiss could restore his confidence; in the long years of his troubled and unstable love and in the loneliness of his manhood; with old age at his elbow it needed but little for his spirit, so easily joyful, to be lost in a strange darkness. In the hands of an ignorant doctor he suffered incredible tortures, and then a new ill befell him. In the summer of 1374 Petrarch died. He writes a wonderful letter to Franceschino full of adoration for Petrarch and anxiety about his works, and signs 'Your Giovanni Boccaccio if he still exists'. 'That letter was his swan song. Infirm and ill as he was he lay there, really alone, and dying. As the days went by he must often have looked from his room over the world that lies there spread out beneath his windows as fair as any in Tuscany; a land of hills about a quiet valley, where the olives are tossed to silver in the wind and the grapes are kissed by the sun into gold and purple, where the corn whispers between the vines-till for him too at last the grasshopper became a burden. On December 21, 1375, he breathed his last. 

THIS BOOK IS DUE ON THE LAST DATE STAMPED BELOW

AN INITIAL FINE OF 25 CENTS WILL BE ASSESSED FOR FAILURE TO RETURN THIS BOOK ON THE DATE DUE. THE PENALTY WILL INCREASE TO 50 CENTS ON THE FOURTH DAY AND TO \$1.00 ON THE SEVENTH DAY OVERDUE.

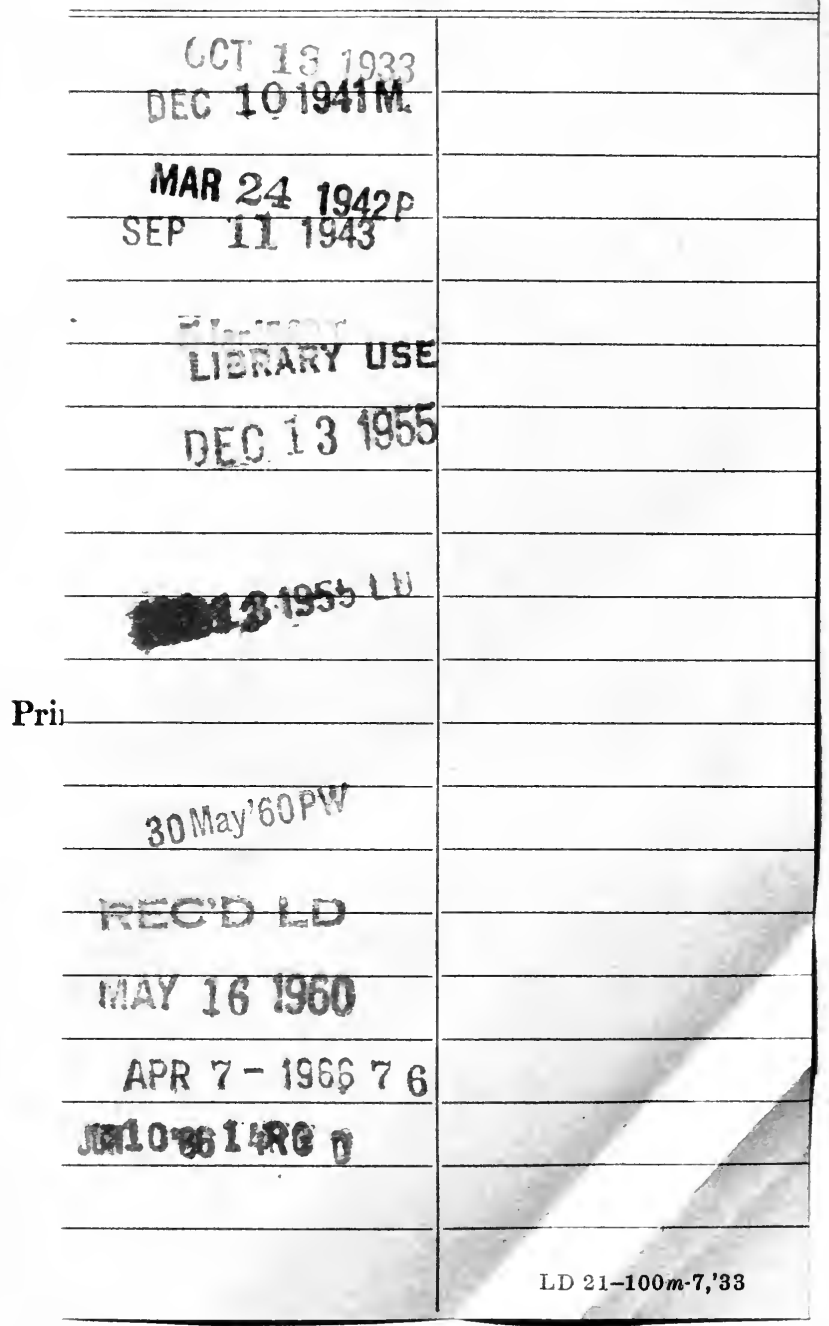


Binder

Gaylord Bros.

Makers

Syracuse, $\mathbf{N}$. $\mathbf{X}$.

PAT. JAN 21, 1908

$$
515+6 ?
$$

UNIVERSITY OF CALIFORNIA LIBRARY 


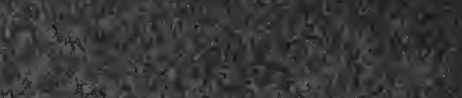

int $30:=$

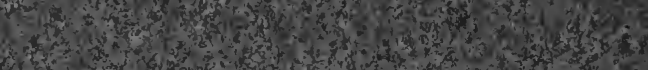

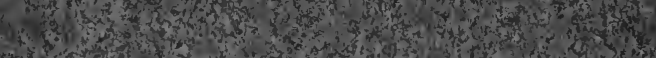

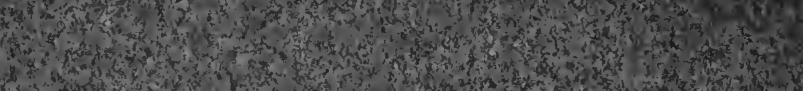

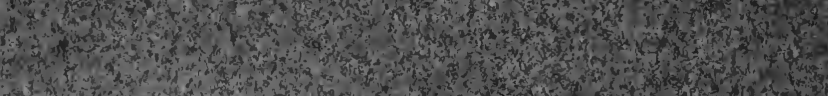

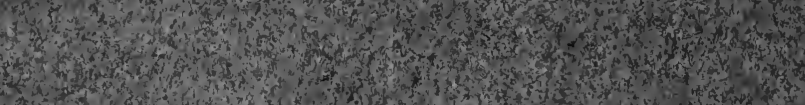

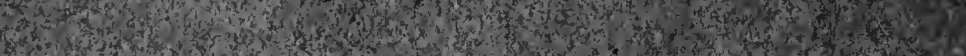
How

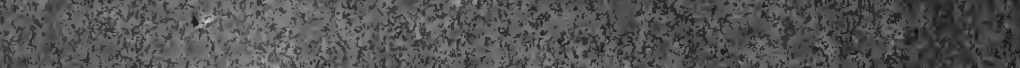

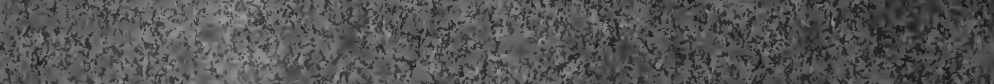

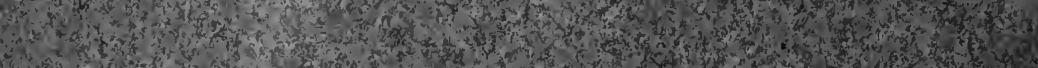

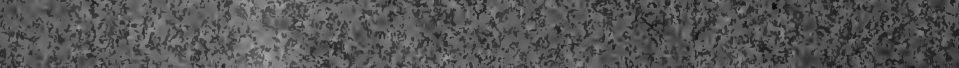
the 1 .

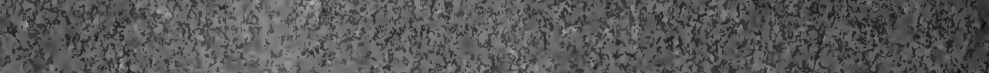

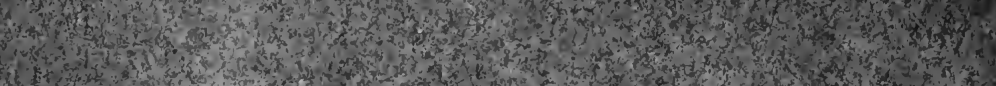

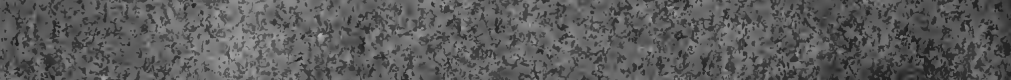

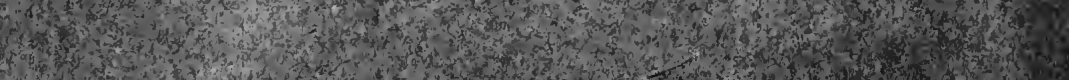

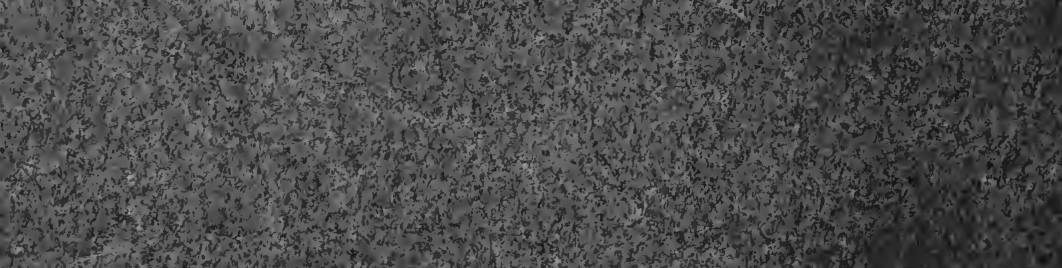
m.

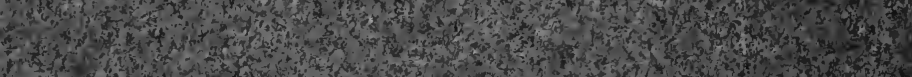
T.

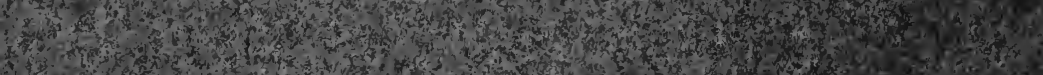

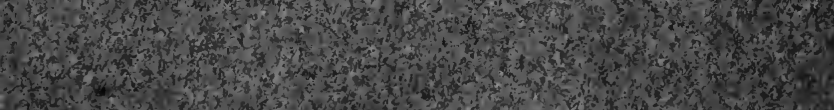

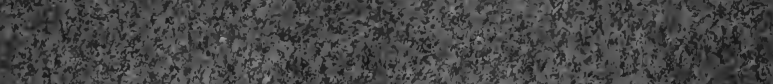

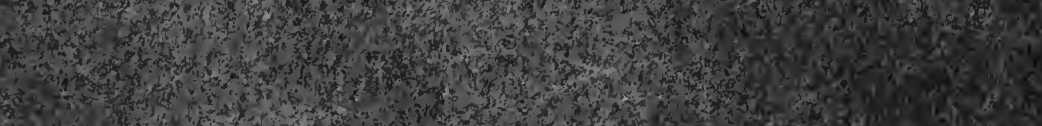

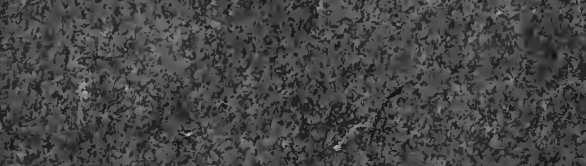

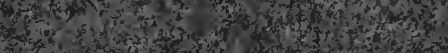

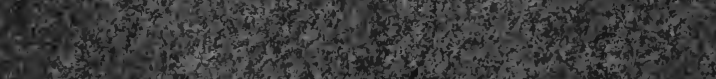

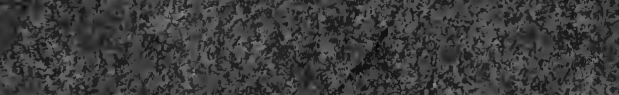

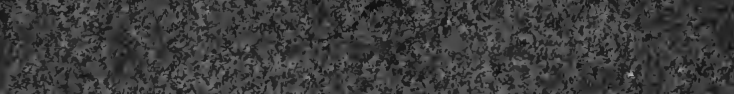

30.

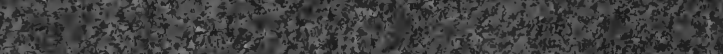

